\title{
Comparison of Public Perception in Desert and Rainy Regions of Chile Regarding the Reuse of Treated Sewage Water
}

\author{
Daniela Segura ${ }^{1}$, Valentina Carrillo ${ }^{1,2}$, Francisco Remonsellez ${ }^{2}$, Marcelo Araya ${ }^{1}$ and \\ Gladys Vidal ${ }^{1, *}$ (iD \\ 1 Engineering and Biotechnology Environmental Group, Environmental Science Faculty \& Center \\ EULA-Chile, University of Concepción, P.O. Box 160-C, Concepción 4070386, Chile; dsegura@udec.cl (D.S.); \\ vcarrillol@udec.cl (V.C.); arayamardones@gmail.com (M.A.) \\ 2 Chemical Engineering Department, Engineering and Geological Science Faculty, Católica del Norte \\ University, P.O. Box 1280, Antofagasta 1240000, Chile; fremonse@ucn.cl \\ * Correspondence: glvidal@udec.cl; Tel.: +56-41-2204-067; Fax: +56-41-2207-076 or +56-041-2661-033
}

Received: 2 February 2018; Accepted: 12 March 2018; Published: 17 March 2018

\begin{abstract}
The objective of this study was to compare the public perception in desert and rainy regions of Chile regarding the reuse of treated sewage water. The methodology of this study consisted of applying a survey to the communities of San Pedro de Atacama (desert region) and Hualqui (rainy region) to identify attitudes about the reuse of sewage water. The survey was applied directly to men and women, 18 to 90 years old, who were living in the studied communities. The results indicate that inhabitants of San Pedro de Atacama (desert region) were aware of the state of their water resources, with $86 \%$ being aware that there are water shortages during some part of the year. In contrast, only $55 \%$ of residents in Hualqui (rainy region) were aware of water shortages. With respect of the reuse of treated sewage water, $47 \%$ of respondents in San Pedro de Atacama understood the concept, as compared to $27 \%$ in Hualqui. There was more acceptance of using treated sewage water for non-potable purposes than as drinking water.
\end{abstract}

Keywords: public perception; water scarcity; reuse; sewage water; desert region; rainy region; Chile

\section{Introduction}

The volume of precipitation in Chile is on the order of 53,000 $\mathrm{m}^{3} /$ inhab/year, which is 26.5 times higher than the minimum requirement for sustainability of $2000 \mathrm{~m}^{3} /$ inhab/year. The volume of precipitation in the desert regions of northern Chile is $800 \mathrm{~m}^{3} /$ inhab/year, which is in stark contrast to the $20,000 \mathrm{~m}^{3} /$ inhab/year in the southern rainy regions of the country [1].

Since 2010, Chile has experienced a 30\% deficit in precipitation, which has resulted in the need to supply drinking water by means of water trucks to southern areas that are considered to be rainy [2]. This temporary solution has cost the Chilean government \$US 87 million [1].

With the ongoing advances in water treatment technologies, the reuse of treated sewage water has become a viable source of water for different applications in the context of water shortages $[3,4]$. There are over 260 sewage water treatment systems in operation in Chile [5]. These conventional treatment systems generate 770 million cubic meters of treated water per year [5]. However, owing to the lack of advanced treatment technologies and the standards that regulate this practice, the reuse of treated sewage water is currently prohibited in Chile [6].

In contrast, projects to reuse sewage water have been successfully undertaken in Israel, Namibia, the USA, Australia, and elsewhere. Nevertheless, there have been few studies into public perception about reusing sewage water and there are few public education and community inclusion programs [7]. 
There is currently opposition among communities to the reuse of treated sewage water [8]. No matter how reasonable the policy may be, public resistance will make its implementation difficult, which is why research into public awareness about water resources and the perceptions about the reuse of treated sewage water are essential for the effective use of this resource $[9,10]$.

There are social factors that are relevant to projects for the reuse of treated sewage water. The degree to which they affect public perception depends on the type of reuse, but all of these factors should be included in the discussion [8]. Among these factors are: disagreement, perceptions of risk, applications for the reuse of treated sewage water, problems of alternatives, sources of the water, trust in authorities, and others [11]. Baggett et al. [12] concluded that the success of sewage water reuse projects depends on the production costs and understanding of the social context in which they are established. Along a similar line, Hartley [13] argued that information, knowledge, and education play important roles in public perception.

While some findings in other parts of the world can be used in Chile, the culture and traditions of original peoples can influence perceptions about and acceptance of the reuse of treated sewage water. Research of this type is valuable for identifying public perceptions that affect future applications of this resource. The aim of this study is to compare the public perception of the desert and rainy regions of Chile about the reuse of treated sewage water.

\section{Methodology}

\subsection{Context of the Study}

\subsubsection{Characteristics of the Study Area}

Two communities were selected for the study, San Pedro de Atacama and Hualqui. Table 1 shows the characterization of the two communities and highlights differences in climate, annual mean temperature $\left({ }^{\circ} \mathrm{C}\right)$, and monthly mean precipitation levels $(\mathrm{mm})$. Figure 1 shows the geographic locations of the two communities. San Pedro de Atacama is located in an area that is the most emblematic in Chile of the problem of water shortages and conflict over water rights. Living in this arid region are original peoples that have contested the water rights of mining operations [14]. The community of Hualqui, on the other hand, is removed from the situation of the Mapuche people that are in conflict with the government over questions of water contamination and the monopolization of river basins, principally for the purpose of generating hydroelectric power [14].

Table 1. Characterization of geography study areas: San Pedro de Atacama and Hualqui.

\begin{tabular}{ccc}
\hline Characteristics & San Pedro de Atacama & Hualqui \\
\hline Region & Antofagasta & Biobío \\
\hline Province & El Loa & $36^{\circ} 57^{\prime} 36^{\prime \prime}$ \\
\hline Latitude & $22^{\circ} 55^{\prime} 0^{\prime \prime}$ & $72^{\circ} 55^{\prime} 48^{\prime \prime}$ \\
\hline Longitude & $68^{\circ} 12^{\prime} 0^{\prime \prime}$ & Warm temper \\
\hline Weather/climate & Cold desert & $12^{\circ} \mathrm{C}\left(9\right.$ to $\left.18^{\circ} \mathrm{C}\right)$ \\
\hline Average/annual range temperature $\left({ }^{\circ} \mathrm{C}\right)$ & $17^{\circ} \mathrm{C}\left(-1\right.$ to $\left.25^{\circ} \mathrm{C}\right)$ & 663.11 mm \\
\hline Average annual precipitation & 44.57 mm & Agriculture, pine plantations \\
\hline Primary and secondary economic activities & Extractions of borax, sodium, potassium & and lithium \\
\hline Tertiary economic activity & Tourism & Tourism \\
\hline Main indigenous group & Atacameños & Mapuches
\end{tabular}



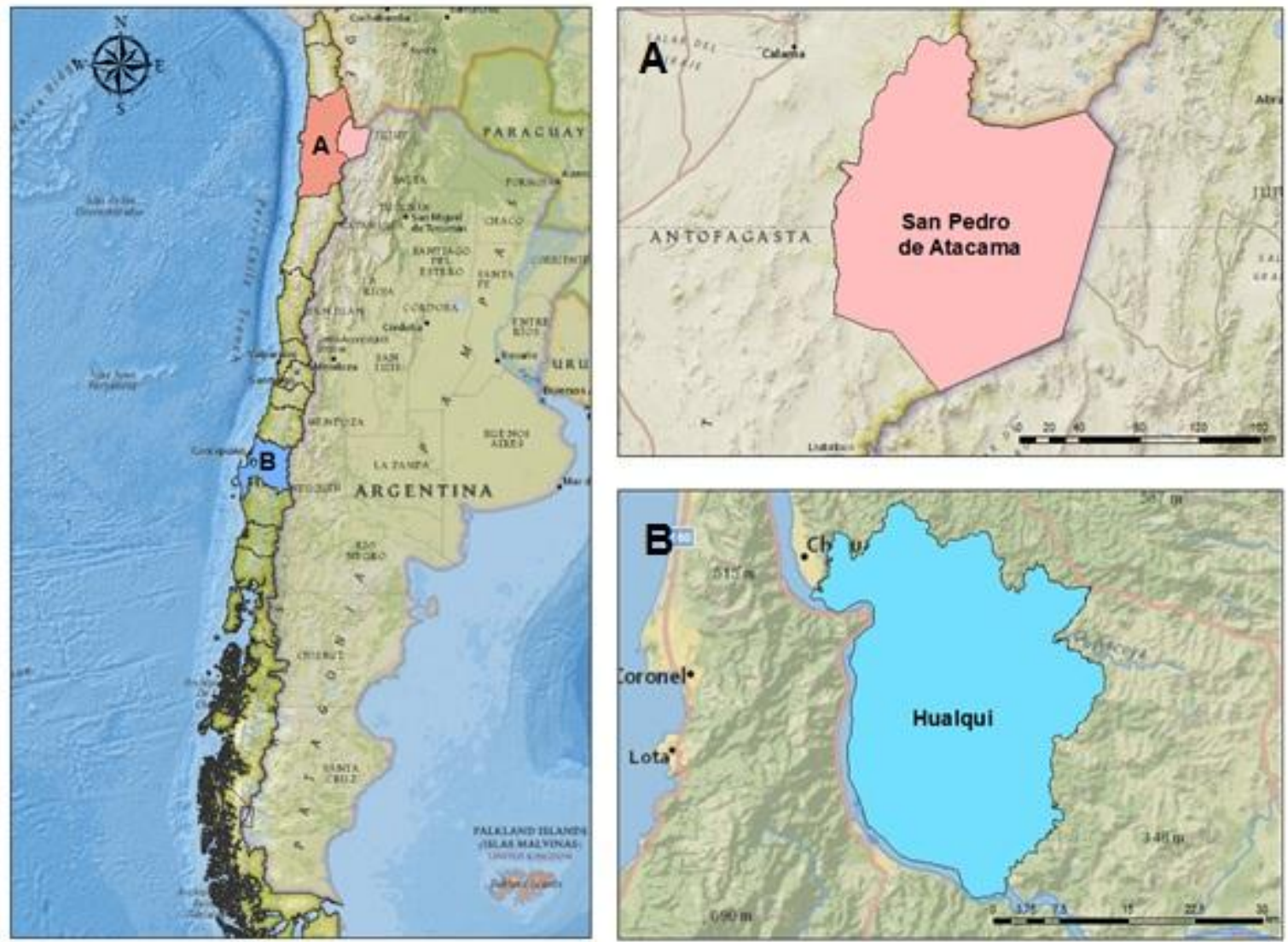

Figure 1. Geographical locations of the survey communities in Chile. (A) Desert region, community under study: San Pedro de Atacama. (B) Humid region, community under study: Hualqui.

\subsubsection{Participants in the Study Areas}

The two communities were characterized demographically. The preliminary results of the 2012 census estimated the population of San Pedro de Atacama was 5605 persons, 2780 are male, and 2825 female. Some $26.0 \%$ of the population is between 0 and 14 years old, $64.8 \%$ is between 15 and 64 , and $9.2 \%$ is over 65 [15]. According to the 2002 census, Atacameñans were the predominant indigenous peoples in the region [16]. The Atacameñans or Likanantai people live in the oasis, valleys, and ravines of Loa Province in Northern Chile. Their main ceremonial centers are Caspana, Peine, Socaire, Toconao, and San Pedro de Atacama [17].

According to the same census in 2012, the population of Hualqui was 23,016 persons, 11,252 males, and 11,764 females. Some $23.1 \%$ of the population was between 0 and 14 years old, $67.5 \%$ between $15 \%$ and $64 \%$, and $9.5 \%$ was over 65 [15]. The 2002 census found that the Mapuche were the predominant indigenous group in the region [16]. The Mapuche had historically settled between the Itata and Toltén Rivers in central southern part of Chile [17].

The surveys included residents of different genders, ages, occupations, and educational levels. Table 2 shows the demographic characterization of respondents in the two communities.

\subsection{Instrument and Its Application}

\subsubsection{Determination of the Sample}

The statistical software STATS ${ }^{\circledR}$ v.3.2 (SAS Institute, Cary, NC, USA) was used to calculate the sample size. The following parameters were established for the calculation: maximum acceptable error 
of $5 \%, 0.5 p$ value, and a $90 \%$ desired level of confidence [18]. With these considerations, the program determined sample sizes of 255 persons in San Pedro de Atacama and 268 in Hualqui.

\subsubsection{Adaptation and Validation of the Instrument}

The instrument was based on a survey applied by Gu et al. [10] to the population of Tianjin, China to determine attitudes about the reuse of treated sewage water. Table 3 shows the survey, which was modified to reflect the situation of Chile, consisting of 37 questions that were divided among three sections: demographic characterization, knowledge about water resources and treated sewage water, and acceptance of the reuse of treated sewage water. The instrument was validated in a three-step process: validation with a panel of experts, field validation, and a pilot test [19].

Table 2. Characteristics of the surveyed group of San Pedro de Atacama and Hualqui.

\begin{tabular}{|c|c|c|c|c|c|}
\hline \multirow{2}{*}{ Demographic Characteristics } & \multirow{2}{*}{ Options } & \multicolumn{2}{|c|}{ San Pedro de Atacama } & \multicolumn{2}{|c|}{ Hualqui } \\
\hline & & Percentage & Frequency & Percentage & Frequency \\
\hline \multirow{2}{*}{ Gender } & Male & 46.3 & 118 & 36.6 & 98 \\
\hline & Female & 53.7 & 137 & 63.4 & 170 \\
\hline \multirow{4}{*}{ Age } & $15-29$ & 19.2 & 49 & 18.7 & 50 \\
\hline & $30-44$ & 41.2 & 105 & 23.5 & 63 \\
\hline & $45-64$ & 30.6 & 78 & 39.9 & 107 \\
\hline & $>65$ & 9.0 & 23 & 17.9 & 48 \\
\hline \multirow{6}{*}{ Occupation } & Student & 1.6 & 4 & 10.1 & 27 \\
\hline & Housewife & 11.4 & 29 & 30.6 & 82 \\
\hline & Self-employed & 43.9 & 112 & 31.0 & 83 \\
\hline & Hired worker & 35.7 & 91 & 17.9 & 48 \\
\hline & Unemployed & 2.4 & 6 & 3.4 & 9 \\
\hline & Retired & 51 & 13 & 7.1 & 19 \\
\hline Total & - & $100 \%$ & 255 & $100 \%$ & 268 \\
\hline
\end{tabular}

Table 3. Questionnaire applied to the group surveyed.

\begin{tabular}{|c|c|}
\hline & Social Background \\
\hline 1. Gender: A. Male; B. Female & \\
\hline 2. Age: A. $15-29 ;$ B. $30-44 ;$ C. $45-64 ;$ D. > 65 & \\
\hline $\begin{array}{l}\text { 3. Education: A. No studies; B. Incomplete basic s } \\
\text { Complete media studies; F. Incomplete technician }\end{array}$ & $\begin{array}{l}\text { Idies; C. Complete basic studies; D. Incomplete media studies; E. } \\
\text { s. Incomplete university; H. Complete technician; I. Complete university }\end{array}$ \\
\hline $\begin{array}{l}\text { 4. Occupation: A. Student; B. Housewife; C. Self- } \\
\text { E. Unemployed; F. Pensioner }\end{array}$ & ployed; D. Hired worker; \\
\hline Knowledge of W & er Resources and Treated Sewage Reuse \\
\hline $\begin{array}{l}\text { 5. Does your house have a sewage disposal syster } \\
\text { A. Yes; B No }\end{array}$ & \\
\hline $\begin{array}{l}\text { 6. What is the main potable water source in your } \\
\text { A. Drinking water supply; B. Groundwater; C. W } \\
\text { E. Water truck; F. Another source }\end{array}$ & $\begin{array}{l}\text { gion? } \\
\text { er well; D. Rivers and reservoirs; }\end{array}$ \\
\hline $\begin{array}{l}\text { 7. Which sector is the biggest user of water in the } \\
\text { A. Agricultural; B. Domestic; C. Industry; D. Min }\end{array}$ & $\begin{array}{l}\text { gion? } \\
\text { g; E. Energy; F. Forest; G. Aquaculture; H. Tourism; I. No idea }\end{array}$ \\
\hline $\begin{array}{l}\text { 8. Does your region have sufficient water? } \\
\text { A. Severe shortage; B. Summer shortage; C. Suffic }\end{array}$ & nt water supply; D. No idea \\
\hline $\begin{array}{l}\text { 9. Where are the wastewater primarily dischargec } \\
\text { A. Wastewater treatment plant (WWTP); B. River } \\
\text { No idea }\end{array}$ & $\begin{array}{l}\text { ond reservoirs without treatment; C. Sea; D. Groundwater infiltration; E. } \\
\text { and }\end{array}$ \\
\hline $\begin{array}{l}\text { 10. Do you use responsible water in your home? } \\
\text { A. Yes; B. No }\end{array}$ & \\
\hline
\end{tabular}


Table 3. Cont

\begin{tabular}{|c|}
\hline Social Background \\
\hline $\begin{array}{l}\text { 11. What activity uses the most water in your house? } \\
\text { A. Cooking; B. Bathing and laundry; C. House cleaning; D. Others }\end{array}$ \\
\hline $\begin{array}{l}\text { 12. Do you use water-saving measures in your home? } \\
\text { A. Yes; B. No }\end{array}$ \\
\hline $\begin{array}{l}\text { 13. Have you ever been asked to use water-saving measures? } \\
\text { A. Yes; B. No }\end{array}$ \\
\hline $\begin{array}{l}\text { 14. Is public usage a waste of water? } \\
\text { A. Yes; B. No }\end{array}$ \\
\hline $\begin{array}{l}\text { 15. Do you know about treated sewage reuse? } \\
\text { A. Yes; B. No }\end{array}$ \\
\hline $\begin{array}{l}\text { 16. If the previous answer was yes, where do you have this knowledge? } \\
\text { A. Media; B. Social organization; C. Government organization; D. Friends or Family; E. Professional knowledge; F. No idea }\end{array}$ \\
\hline 17. What do you understand by treated sewage reuse? \\
\hline $\begin{array}{l}\text { 18. Do you have previous experience with treated sewage reuse? } \\
\text { A. Yes; B. No }\end{array}$ \\
\hline $\begin{array}{l}\text { 19. In your opinion, is treated sewage reuse useful to face water shortages? } \\
\text { A. Yes; B. No }\end{array}$ \\
\hline $\begin{array}{l}\text { 20. In your opinion, who must be in charge of generating treated sewage reuse? } \\
\text { A. Government; B. Private Company; C. Community; D. Other }\end{array}$ \\
\hline $\begin{array}{l}\text { 21. Will you trust in the water quality? } \\
\text { A. Yes; B. No; C. No idea; D. No comment }\end{array}$ \\
\hline $\begin{array}{l}\text { 22. Would you be willing to pay for the additional treatment? } \\
\text { A. Yes; B. No; C. No idea; D. No comment }\end{array}$ \\
\hline Public Acceptability toward Treated Sewage Reuse \\
\hline $\begin{array}{l}\text { 23. Do you accept reuse of treated sewage for potable domestic purpose? } \\
\text { A. Strongly agree; B. Agree; C. Neither agree nor disagree; D. In disagreement; E. Strongly disagree }\end{array}$ \\
\hline $\begin{array}{l}\text { 24. Do you accept reuse of treated sewage for non-potables domestic purposes? } \\
\text { A. Strongly agree; B. Agree; C. Neither agree nor disagree; D. In disagreement; E. Strongly disagree }\end{array}$ \\
\hline $\begin{array}{l}\text { 25. Do you accept reuse of treated sewage for fountains? } \\
\text { A. Strongly agree; B. Agree; C. Neither agree nor disagree; D. In disagreement; E. Strongly disagree }\end{array}$ \\
\hline $\begin{array}{l}\text { 26. Do you accept reuse of treated sewage for landscape irrigation? } \\
\text { A. Strongly agree; B. Agree; C. Neither agree nor disagree; D. In disagreement; E. Strongly disagree }\end{array}$ \\
\hline $\begin{array}{l}\text { 27. Do you accept reuse of treated sewage for toilet flushing? } \\
\text { A. Strongly agree; B. Agree; C. Neither agree nor disagree; D. In disagreement; E. Strongly disagree }\end{array}$ \\
\hline $\begin{array}{l}\text { 28. Do you accept reuse of treated sewage for car washing? } \\
\text { A. Strongly agree; B. Agree; C. Neither agree nor disagree; D. In disagreement; E. Strongly disagree }\end{array}$ \\
\hline $\begin{array}{l}\text { 29. Do you accept reuse of treated sewage for road dust control? } \\
\text { A. Strongly agree; B. Agree; C. Neither agree nor disagree; D. In disagreement; E. Strongly disagree }\end{array}$ \\
\hline $\begin{array}{l}\text { 30. Do you accept reuse of treated sewage for groundwater infiltration? } \\
\text { A. Strongly agree; B. Agree; C. Neither agree nor disagree; D. In disagreement; E. Strongly disagree }\end{array}$ \\
\hline $\begin{array}{l}\text { 31. Do you accept reuse of treated sewage for agricultural irrigation at ground level? } \\
\text { A. Strongly agree; B. Agree; C. Neither agree nor disagree; D. In disagreement; E. Strongly disagree }\end{array}$ \\
\hline $\begin{array}{l}\text { 32. Do you accept reuse of treated sewage for agricultural trees irrigation? } \\
\text { A. Strongly agree; B. Agree; C. Neither agree nor disagree; D. In disagreement; E. Strongly disagree }\end{array}$ \\
\hline $\begin{array}{l}\text { 33. Do you accept reuse of treated sewage for industrial processes? } \\
\text { A. Strongly agree; B. Agree; C. Neither agree nor disagree; D. In disagreement; E. Strongly disagree }\end{array}$ \\
\hline
\end{tabular}

\subsubsection{Application of the Instrument}

The instrument was applied directly to the respondents, with the aid of students that had been trained previously on the theme and objectives of the research. 


\subsection{Data Analysis}

\subsubsection{Frequency Analysis}

Following the application of the survey, a statistical analysis of the data was applied with the use of the software the SPSS Statistics version 20, which yielded the responses of survey participants to the different objectives of the research, in accordance with the procedure of $\mathrm{Gu}$ et al. [10].

\subsubsection{Chi Square Test}

A chi square statistical contrast was used to identify dependent relationships between the respondents' knowledge and their age and educational level, with a 95\% level of confidence and 0.05 level of significance [20].

\subsubsection{Intention of Use}

Respondents were asked about their level of acceptance of eleven scenarios in which it is planned to reuse treated sewage water. The response options ranged from "strongly agree" to "strongly disagree". Additionally, the intention to use was calculated for these questions with a score to the possible responses of $5,4,3,2$, and 1 , with 5 being the most favorable, in this case, the "strongly agree" response. The following formula was used:

$$
\mathrm{W}_{\mathrm{j}}=\frac{\left(\mathrm{S}_{5} \times 5\right)+\left(\mathrm{S}_{4} \times 4\right)+\left(\mathrm{S}_{3} \times 3\right)+\left(\mathrm{S}_{2} \times 2\right)+\left(\mathrm{S}_{1} \times 1\right)}{\left(\mathrm{S}_{1}+\mathrm{S}_{2}+\mathrm{S}_{3}+\mathrm{S}_{4}+\mathrm{S}_{5}\right)}
$$

where $W_{j}$ is the intention to use for the different proposed scenarios and S1, S2, S3, S4, and S5 are, respectively, the number of respondents that chose the first, second, third, fourth, and fifth option [10].

\section{Results}

\subsection{Knowledge of Water Source and Treated Sewage Water}

Table 4 shows the comparison between respondents from San Pedro de Atacama and Hualqui in relation to their knowledge about water resources in terms of availability, local use, and subsequent treatment (questions 6 to 10). Some 84.7\% of respondents in San Pedro de Atacama have access to drinking water through the public system, when compared to $78.4 \%$ in Hualqui. The second option for water supply in San Pedro de Atacama is water trucks (5.1\%), while in Hualqui it is by wells (7.8\%).

With respect to knowledge about the use of water resources, $41.2 \%$ of respondents in San Pedro de Atacama knew that the mining sector accounted for the highest levels of water consumption, while respondents in Hualqui did not know about water consumption by productive sectors. Some $27.6 \%$ erroneously thought that tourism was the main consumer of water.

In terms of water availability, the residents of San Pedro de Atacama were aware of summer water shortages $(51.0 \%)$, while, in the rainy region, $49.3 \%$ of respondents thought there was sufficient water within the region. More than $60 \%$ of respondents in both of the regions knew about the final destination of sewage water. Moreover, the results of the chi-squared test confirmed that the knowledge of the state of water resources in both communities is not dependent on age or educational level.

Table 5 compares the knowledge about the reuse of treated sewage water in the two regions. Some $47.1 \%$ of respondents in the desert area were familiar with the treated sewage reuse concept. However, just the $29.1 \%$ of respondents in the rainy area know the treated sewage reuse concept. Knowledge about the reuse of treated sewage water comes from different sources, the most important in San Pedro de Atacama being professional knowledge, while in Hualqui it is the mass media. For San Pedro de Atacama, the chi-square test indicated that the knowledge regarding the reuse of treated wastewater is dependent on the educational level of the respondents. On the contrary, for Hualqui the knowledge is independent of the age and educational level of the respondents. 
Table 4. Public knowledge with regard to water resources. .

\begin{tabular}{|c|c|c|c|c|c|}
\hline Question & Options & \multicolumn{2}{|c|}{ San Pedro de Atacama } & \multicolumn{2}{|c|}{ Hualqui } \\
\hline \multirow{4}{*}{$\begin{array}{l}\text { What is the main potable water } \\
\text { source in your region? }\end{array}$} & Drinking water supply & 84.7 & 216 & 78.4 & 210 \\
\hline & Water well & 4.7 & 12 & 1.5 & 4 \\
\hline & Rivers and reservoirs & 4.7 & 12 & 6.3 & 17 \\
\hline & Water truck & 5.1 & 13 & 4.5 & 12 \\
\hline \multirow{6}{*}{$\begin{array}{l}\text { Which sector is the biggest user of } \\
\text { water in the region? }\end{array}$} & Agricultural & 5.5 & 14 & 15.3 & 41 \\
\hline & Domestic & 5.1 & 13 & 26.1 & 70 \\
\hline & Industry & 0.4 & 1 & 2.2 & 6 \\
\hline & Mining & 41.2 & 105 & - & - \\
\hline & Energy & 0.4 & 1 & - & - \\
\hline & Forest & - & - & 15.3 & 41 \\
\hline \multirow{4}{*}{$\begin{array}{l}\text { Does your region have sufficient } \\
\text { water? }\end{array}$} & Severe shortage & 36.5 & 93 & 15.3 & 41 \\
\hline & Summer shortage & 51.0 & 130 & 33.6 & 90 \\
\hline & Sufficient water supply & 12.5 & 32 & 49.3 & 132 \\
\hline & No idea & - & - & 1.9 & 5 \\
\hline \multirow{4}{*}{$\begin{array}{l}\text { Where are the wastewater } \\
\text { primarily discharged to? }\end{array}$} & WWTP & 76.1 & 194 & 65.3 & 175 \\
\hline & $\begin{array}{l}\text { Rivers and reservoirs } \\
\text { without treatment }\end{array}$ & 0.4 & 1 & 4.1 & 11 \\
\hline & Groundwater infiltration & 21.6 & 55 & 25.7 & 69 \\
\hline & No idea & 2.0 & 5 & 4.9 & 13 \\
\hline Total & - & $100 \%$ & 255 & $100 \%$ & 268 \\
\hline
\end{tabular}

WWTP: Wastewater treatment plant.

Table 5. Public knowledge with regard to treated sewage reuse.

\begin{tabular}{|c|c|c|c|c|c|}
\hline Question & Options & \multicolumn{2}{|c|}{ San Pedro de Atacama } & \multicolumn{2}{|c|}{ Hualqui } \\
\hline Do you know about treated sewage reuse? & Yes & 47.1 & 120 & 29.1 & 78 \\
\hline \multirow[t]{3}{*}{$\begin{array}{c}\text { If the previous answer was yes, where do } \\
\text { you have this knowledge? }\end{array}$} & Media & 16.1 & 41 & 17.9 & 48 \\
\hline & Friends or Family & 6.3 & 16 & 2.2 & 6 \\
\hline & $\begin{array}{l}\text { Professional } \\
\text { Knowledge }\end{array}$ & 16.5 & 42 & 7.8 & 21 \\
\hline
\end{tabular}

\subsection{Public Perception towards Treated Sewage Reuse}

Table 6 shows the views of respondents in the two regions about treated sewage water. In both communities, over $70 \%$ of respondents considered that sewage water is a useful source of water supply in view of the current situation of drought. Some $45.5 \%$ of respondents in the desert region stated that the state should manage the reuse of treated sewage water, while $32.2 \%$ thought that the community should have this responsibility. In the rainy region, $75.4 \%$ identified the government and $16.4 \%$ identified the private sector.

Respondents in both regions stated that they would be willing to assume production costs. There was a marked difference in the level of confidence in the quality of treated sewage water, with $69.8 \%$ in San Pedro de Atacama trusting in the quality, while $49.3 \%$ in Hualqui felt the same. 


\subsection{Public Acceptability of Treated Sewage Reuse}

Table 7 shows the relative acceptance of the reuse of sewage water based on responses to the eleven different questions. There was more than $50 \%$ acceptance for the reuse of sewage water where the application was not as drinking water. Respondents showed concern about the use of sewage water as domestic drinking water, with only $35.3 \%$ and $33.6 \%$ of acceptance by respondents in San Pedro de Atacama and Hualqui, respectively.

Table 6. Perception of community in San Pedro de Atacama and Hualqui toward treated sewage reuse.

\begin{tabular}{|c|c|c|c|c|c|}
\hline \multirow{2}{*}{ Question } & \multirow{2}{*}{ Options } & \multicolumn{2}{|c|}{ San Pedro de Atacama } & \multicolumn{2}{|c|}{ Hualqui } \\
\hline & & Percentage & Frequency & Percentage & Frequency \\
\hline $\begin{array}{l}\text { In your opinion, the treated sewage reuse } \\
\text { it's useful to face water shortage? }\end{array}$ & Yes & 90.6 & 231 & 79.5 & 213 \\
\hline \multirow{3}{*}{$\begin{array}{l}\text { In your opinion, who must be in charge of } \\
\text { generating treated sewage reuse? }\end{array}$} & Government & 45.5 & 116 & 75.4 & 202 \\
\hline & Private Company & 17.6 & 45 & 16.4 & 44 \\
\hline & Community & 32.2 & 82 & 4.5 & 12 \\
\hline \multirow{4}{*}{ Will you trust in the water quality? } & Yes & 69.8 & 178 & 49.3 & 132 \\
\hline & No & 24.7 & 63 & 42.9 & 115 \\
\hline & No idea & 5.5 & 14 & 7.8 & 21 \\
\hline & No comment & - & - & - & - \\
\hline \multirow{2}{*}{$\begin{array}{l}\text { Would you be willing to pay for the } \\
\text { additional treatment? }\end{array}$} & Yes & 71.8 & 183 & 60.8 & 163 \\
\hline & No & 21.6 & 55 & 34.0 & 91 \\
\hline
\end{tabular}

Table 7. Public acceptability of treated sewage reuse in San Pedro de Atacama and Hualqui.

\begin{tabular}{|c|c|c|c|c|c|c|c|c|c|c|c|c|}
\hline \multirow{2}{*}{ Question \# } & \multicolumn{6}{|c|}{ San Pedro de Atacama } & \multicolumn{6}{|c|}{ Hualqui } \\
\hline & SA & $\mathbf{A}$ & NN & ID & SD & UI & SA & A & NN & ID & SD & UI \\
\hline 23 & 4.3 & 35.3 & 5.5 & 32.9 & 22.0 & 2.67 & 1.1 & 33.6 & 5.6 & 50.0 & 9.7 & 2.66 \\
\hline 24 & 14.9 & 65.1 & 7.5 & 7.8 & 4.7 & 3.78 & 8.6 & 72.8 & 3.4 & 14.2 & 1.1 & 3.74 \\
\hline 25 & 25.9 & 50.6 & 3.5 & 13.7 & 6.3 & 3.76 & 5.6 & 72.4 & 1.1 & 18.3 & 2.6 & 3.60 \\
\hline 26 & 34.1 & 62.0 & - & 3.5 & 0.4 & 4.26 & 7.5 & 83.6 & 0.4 & 7.5 & 1.1 & 3.89 \\
\hline 27 & 37.3 & 56.1 & 0.8 & 5.5 & 0.4 & 4.26 & 10.8 & 85.8 & 0.4 & - & 3.0 & 4.04 \\
\hline 28 & 31.4 & 51.8 & 1.2 & 12.2 & 3.5 & 3.95 & 9.0 & 72.8 & 0.7 & 14.9 & 2.6 & 3.71 \\
\hline 29 & 36.9 & 45.1 & 2.0 & 14.5 & 1.6 & 4.01 & 9.3 & 73.1 & 0.7 & 13.1 & 3.7 & 3.71 \\
\hline 30 & 14.9 & 49.8 & 9.4 & 17.6 & 8.2 & 3.45 & 4.5 & 64.6 & 4.1 & 25.0 & 1.9 & 3.45 \\
\hline 31 & 29.4 & 53.7 & 5.1 & 11.0 & 0.8 & 4.00 & 4.9 & 70.1 & 1.5 & 21.3 & 2.2 & 3.54 \\
\hline 32 & 31.8 & 57.3 & 2.4 & 7.8 & 0.8 & 4.11 & 5.6 & 84.0 & 1.1 & 8.6 & 0.7 & 3.85 \\
\hline 33 & 27.5 & 47.1 & 7.5 & 14.5 & 3.5 & 3.80 & 9.0 & 68.7 & 4.9 & 17.2 & 0.4 & 3.68 \\
\hline
\end{tabular}

SA: strongly agree; A: agree; NN: neither agree nor disagree; ID: in disagreement; SD: strongly disagree; UI: use intention. "Question: 23: Do you accept reuse of treated sewage for potable domestic purpose?; 24: Do you accept reuse of treated sewage for non-potables domestic purposes?; 25: Do you accept reuse of treated sewage for fountains?; 26: Do you accept reuse of treated sewage for landscape irrigation?; 27: Do you accept reuse of treated sewage for toilet flushing?; 28: Do you accept reuse of treated sewage for car washing?; 29: Do you accept reuse of treated sewage for road dust control?; 30: Do you accept reuse of treated sewage for groundwater infiltration?; 31: Do you accept reuse of treated sewage for agricultural irrigation at ground level?; 32: Do you accept reuse of treated sewage for agricultural trees irrigation?; 33: Do you accept reuse of treated sewage for industrial processes?

In relation to the intention to use, the average level of acceptance was above 3 for 10 of the 11 scenarios. The scenario of drinking water use had the lowest support in both of the regions, with an average score above 2. The level of acceptance of using treated sewage water as drinking water was independent of age and education level in both regions, while acceptance of the use of treated sewage water for non-potable domestic purposes was age dependent, with the least acceptance among respondents in the group 45 to 64 years old. 


\section{Discussion}

\subsection{Availability and Uses of Water Resources in Chile}

Recurring and prolonged droughts in Chile have made evident the need for a national water resources policy focused on sustainability and the common good that articulates the interests of the different actors involved and takes into consideration the unique characteristics of the country. Figure 2 shows the responses of survey participants on the matter of water availability in their respective regions. It can be noted that people in Hualqui are not aware of the droughts that affected the country from 2010 to 2015. Notably, the National Emergency Office spent almost \$US 30,000 to rent water trucks in this region. In contrast, Gu et al. [10] found that, in Tianjin, where there was drought at the time of the study, $78 \%$ of respondents were aware of the situation.

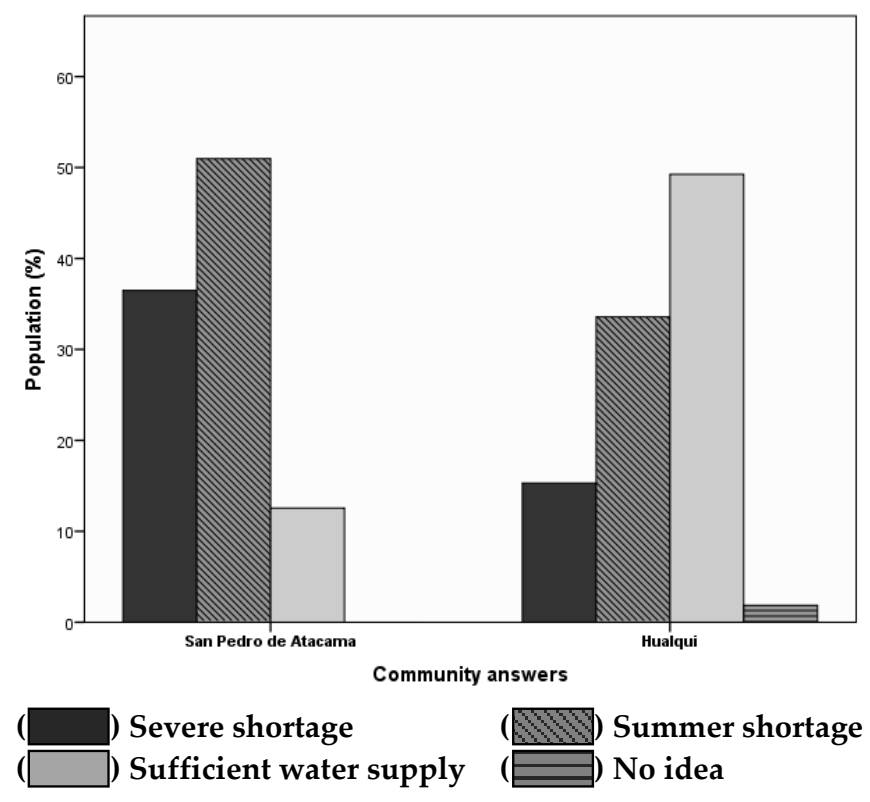

Figure 2. Water availability in San Pedro de Atacama and Hualqui.

Respondents in San Pedro de Atacama are aware there is a water shortage, but associate this with the summer and increased tourism in the region. The $36.5 \%$ of survey participants that responded that there is a severe drought in the region are from areas with a high percentage of indigenous people. Thus, the perceptions about climate behavior are based on direct experience and the observation of rain and snowfall and how, year-by-year, these affect the availability of grasses and water [14]. The manifestations of changes in climate can be more evident in more fragile environments like glaciers and deserts. This is why Atacameñans that live in the Atacama Desert have perceived the changes that have been taking place since the mid-20th century through the exercise of their traditional activities, like shepherding and farming [14].

Agriculture is currently the main water consumer in Chile, using around $73 \%$ of total water resources, while mining and industrial uses account together for $21 \%$ and water utility companies account for $6 \%$. Hydroelectric generation makes the greatest non-consuming use of water resources. The level of competition among these users varies from one part of the country to another and is particularly acute in the northern and central parts of country where all the available surface water has been assigned since 1981, when in the context of the introduction of new Political Constitution, the government established the Water Code. Consistent with the government's general orientation, the new legislation on water had a clear purpose of establishing property rights, not about water itself, but about water use, and to facilitate the orderly functioning of the market [21]. 
Figure 3 shows the answers of respondents in the two regions to the question about which economic sector consume the most water in their region. Some 43.9\% in San Pedro de Atacama and $27.6 \%$ in Hualqui identified tourism as the main consumer, which shows a lack of knowledge among the public about water resources. Mining consumes the most water in San Pedro de Atacama, at $15.259 \mathrm{~m}^{3} / \mathrm{s}$, while energy generation is the major water consumer in Hualqui, at 1,409,240 m³ $/ \mathrm{s}$ [1]. This lack of knowledge is not limited to Chile; a similar study in the community of Tianjin, China found that only $4.7 \%$ of respondents knew that agriculture was the main water consumer in their region [10].

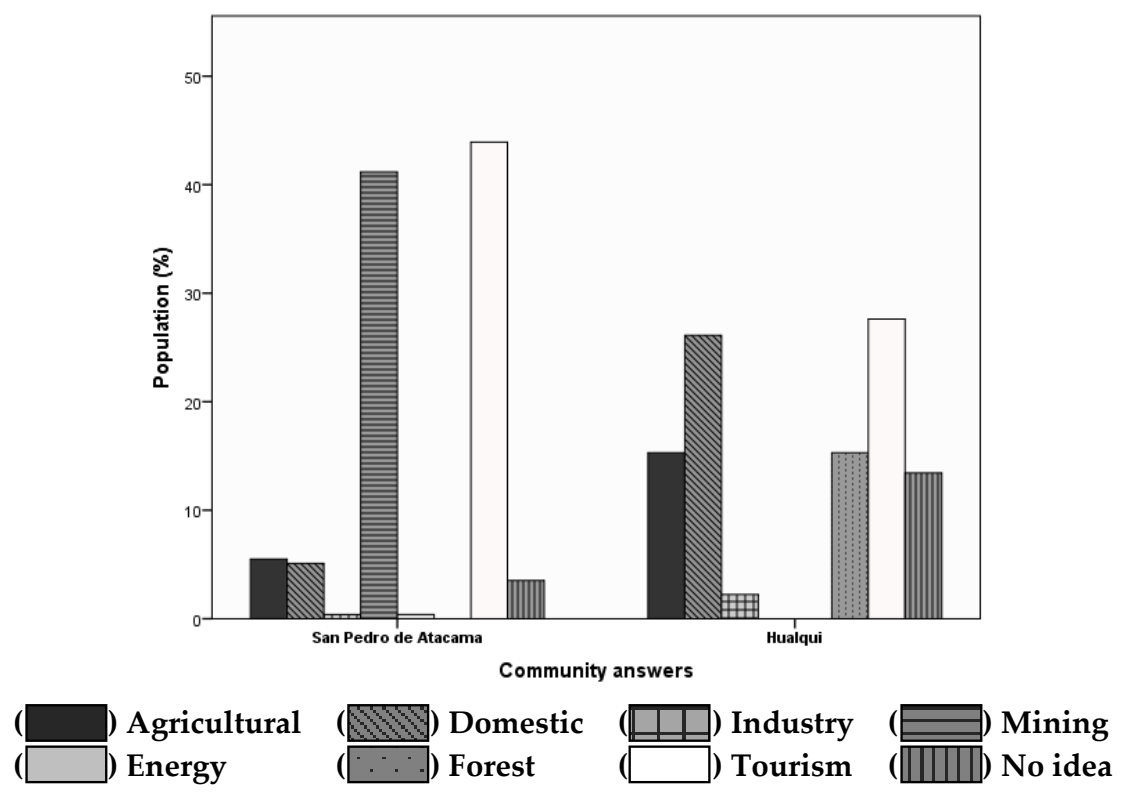

Figure 3. Main users of water in San Pedro de Atacama and Hualqui.

\subsection{Sewage Treatment in Chile}

Currently, Chile has around 100\% sanitation in concentrated areas. Nowadays, more than 260 sewage water treatment plants are operative in Chile. However, just $11.13 \%$ of rural areas have sewage effluent treated. Table 8 shows the treatment plants in the regions under study, together with the most emblematic plants in the country. Some $76.1 \%$ of respondents in San Pedro de Atacama were aware that sewage effluents from their homes went to a treatment plant, when compared to $65.3 \%$ of respondents in Hualqui. In spite of this, most of the installed wastewater treatment technology just reduces the organic matter of the sewage effluents follow by disinfection [22,23]. Most of the nutrient and the micropollutants are being discharged to surface watersheds [24,25]. The level of the wastewater treatment is very important in terms of the reuse. From this perspective, the elimination of toxicity of the discharges that are going to be reused is very important [26].

Table 8. Construction of wastewater treatment facilities in study areas.

\begin{tabular}{ccccc}
\hline Wastewater Treatment Plant & Capacity $\left(\mathbf{m}^{3} / \mathbf{s}\right)$ & Type of Technology & Receiver Course & Start of Operations \\
\hline WWTP-Gran Concepción & 1.7 & Activated mud & Biobío river & 2002 \\
WWTP-Hualqui & 0.026 & Activated mud & Hualquiestero & 2005 \\
WWTP-Gran Antofagasta & 1.5 & Submarine outfalls & Sea & 2003 \\
WWTP-San Pedro de Atacama & 0.011 & Desalination & Infiltration & 1998 \\
WWTP-El Trebal & 4.4 & Activated mud & Mapocho river & 2001 \\
WWTP-La Farfana & 8.5 & Activated mud & Mapocho river & 2003 \\
\hline
\end{tabular}

WWTP: Wastewater treatment plant. 


\subsection{Public Perception of the Reuse of Treated Sewage Water}

The communities in both regions lack basic knowledge about the state of local water resources and their reuse. While more than $60 \%$ of respondents in both regions knew the final destination of sewage water, they did not have knowledge of the processes that occur in treatment plants. Consequently, when asked about the reuse of treated sewage water, $41.7 \%$ of respondents in San Pedro de Atacama stated that they understood the process, while only $29.1 \%$ stated the same in Hualqui. The results of the chi-squared test for San Pedro de Atacama could be explained by the inclusion of environmental education in the school curriculum that was designed to raise awareness of the surrounding environmental. Gu et al. [10] found that the age, education level, and socioeconomic level of respondents are weakly related to their knowledge about the reuse of treated sewage water.

Some $69.8 \%$ of respondents in San Pedro de Atacama expressed confidence in water treatment and the optimal quality of the water, when compared to only $49.3 \%$ that felt the same in Hualqui. This response can be conditioned by the factor of the "problem of alternatives". This factor indicates that in places where there are problems of water shortages, the populations is more accepting of the reuse of treated sewage water and have more confidence in treatment, owing to greater awareness about the need to conserve water resources [27]. Nevertheless, both of the surveyed communities would be willing to assume the costs of treating sewage water, with $71.8 \%$ in favor in San Pedro de Atacama and $60.8 \%$ in Hualqui. In contrast, Marks et al. [28] found that most people are not willing to pay or expect to pay less to reuse treated sewage water, owing to the quality of the water and the restrictions on its use.

Figure 4 shows the responses about who should manage the reuse of treated sewage water. In San Pedro de Atacama $45.5 \%$ of respondents identified the government and $32.2 \%$ identified the community, while in Hualqui $70 \%$ identified the government. This difference could be due to water-related conflicts among northern indigenous communities (Aymara and Atacameñans or Likanantai), the private sector and the government. In this part of the country indigenous peoples lost ancestral water rights with the establishment of the Water Code [14].

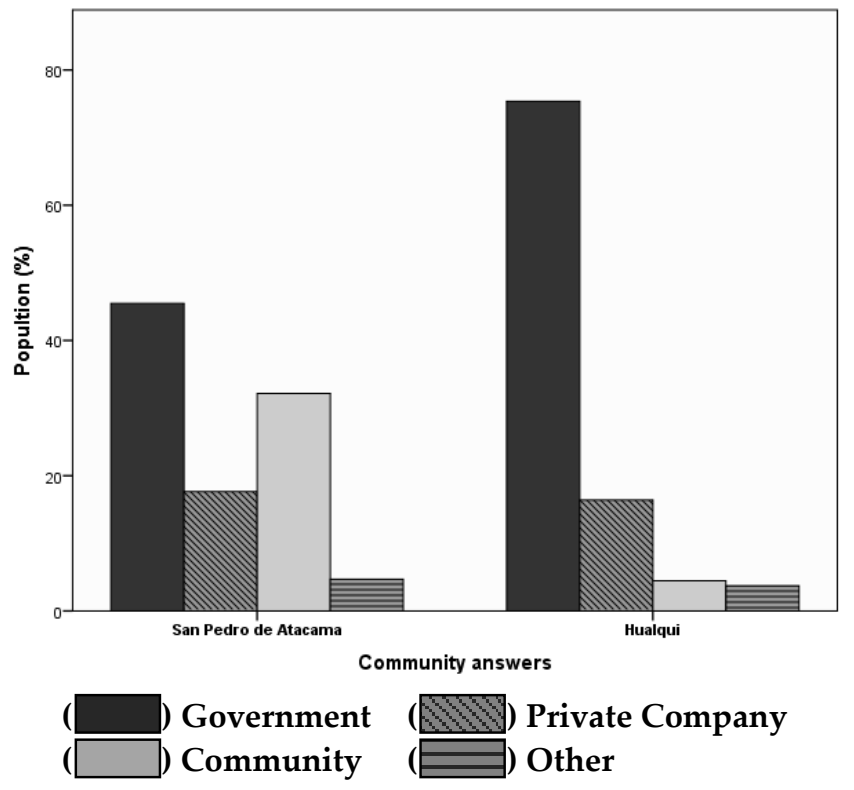

Figure 4. Management responsible for sewage treated use for reuse.

Finally, with respect to the levels of acceptance of the eleven scenarios presented, the reuse of treated sewage water for drinking purposes obtained 35.3\% and 33.6\% approval in San Pedro de Atacama and Hualqui, respectively. The disgust factor, which is defined as an instinctive aversion by the public to drinking or being in contact with treated sewage water was the main reason for the 
low approval [29]. The degree of acceptance of the reuse of treated sewage water as drinking water was independent of age and education level, while the acceptance of the use for non-potable domestic purposes was dependent on the age of respondents in both communities. Acceptance was lowest among respondents in the age group 45 to 64 years. This is confirmed by Hurlimann and McKay [30], who concluded that there is greater opposition to this source of water supply from persons over 50 years old.

\section{Conclusions}

There were differences in the perceptions about the reuse of treated sewage water between survey respondents from San Pedro de Atacama and those that were from Hualqui. Some $90.6 \%$ of respondents in the desert region feel that this technique is useful to reduce the water shortages that they experience daily. In contrast, $79.5 \%$ of respondents in the rainy region felt that this would be a good alternative, while the remaining percentage did not have confidence in the process or the quality of the resulting water, believing that it be a source of health problems.

The surveyed communities in the regions under study did not know about the state of water resources, even though they are located in areas where there are $30 \%$ shortfalls in rainfall. The situation was similar with regard to knowledge about the main water consumers. Some $41.2 \%$ of respondents in San Pedro de Atacama correctly identified mining as the main consumer, which is due the decades old conflict between the mining sector and indigenous peoples.

When considering that the non-potable uses of water are more accepted, one of the best ways to introduce the reuse of treated sewage water is in the context of non-potable applications where there is a more positive attitude.

Acknowledgments: This work was supported by grant no. 13.3327-IN.IIP INNOVA BIOBIO, CORFO 2016-67529 and CONICYT/FONDAP/15130015.

Author Contributions: Gladys Vidal, Francisco Remonsellez and Marcelo Araya conceived and designed the experiments; Daniela Segura and Valentina Carrillo performed the experiments; Daniela Segura analyzed the data; Valentina Carrillo, Francisco Remonsellez, Marcelo Araya and Gladys Vidal contributed with materials and analysis tools; Gladys Vidal and Daniela Segura wrote the paper.

Conflicts of Interest: The authors declare no conflict of interest.

\section{References}

1. Ministry of the Interior and Public Security (MIPS). National Policy for Water Resources. Chilean Government, 2015. Available online: http://www.interior.gob.cl/media/2015/04/recursos_hidricos.pdf (accessed on 15 August 2016). (In Spanish)

2. Center for Climate Science and Resilience (CR2). The Mega Drought 2010-2015: A Lesson for the Future. 2015. Available online: http://www.forestal.uach.cl/manejador/resources/2015informe-a-la-nacinlamegasequia-2010-2015una-leccion-para-el-futuro-1.pdf (accessed on 20 September 2016). (In Spanish)

3. Elimelech, M. The global challenge for adequate and safe water. J. Water Suppl. Res. Technol. AQUA 2006, 55, 3-10. [CrossRef]

4. Pereira, L.S.; Oweis, T.; Zairi, A. Irrigation management under water scarcity. Agric. Water Manag. 2002, 57, 175-206. [CrossRef]

5. Superintendence of Sanitary Services (SSS). Wastewater Treatment System. Chilean Government, 2016. Available online: http://www.siss.gob.cl/577/w3-article-4373.html (accessed on 15 May 2016).

6. Ministry of Social Development (MSD). Methodology Formulation and Evaluation of Evacuation Projects, Treatment and Sewage Disposal in Rural Sector. Chilean Government, 2015. Available online: http: / / docplayer.es/17138750-Metodologia-formulacion-y-evaluacion-de-proyectos-de-evacuaciontratamiento-y-disposicion-de-aguas-servidas-sector-rural.html (accessed on 15 August 2016).

7. Recycled Water Task Force. White Paper of the Public Information, Education and Outreach Workgroup on Better Public Involvement in the Recycled Water Decision Process; The State of California Department of Water Resources: Sacramento, CA, USA, 2003. 
8. Po, M.; Nancarrow, B.; Kaercher, J. Literature Review of Factors Influencing Public Perceptions of Water Reuse; Report to Australian Urban Water Conservation and Reuse Research Program; CSIRO Land and Water: Floreat, Australia, 2003.

9. Zhang, Z.; Balay, J. How much is too much?: Challenges to water withdrawal and consumptive use management. J. Water Resour. Plan. Manag. 2014, 140, 01814001. [CrossRef]

10. Gu, Q.; Chen, Y.; Pody, R.; Cheng, R.; Zheng, X.; Zhang, Z. Public perception and acceptability toward reclaimed water in Tianjin. Resour. Conserv. Recycl. 2015, 104, 291-299. [CrossRef]

11. Jeffrey, P.; Jefferson, B. Public receptivity regarding "in-house” water recycling: Results from a UK survey. Water Sci. Technol. Water Suppl. 2013, 3, 109-116.

12. Baggett, S.; Jeffrey, P.; Jefferson, B. Risk perception in participatory planning for water reuse. Desalination 2006, 187, 149-158. [CrossRef]

13. Hartley, T. Public perception and participation in water reuse. Desalination 2006, 187, 115-126. [CrossRef]

14. Yañez, N.; Molina, R. Indigenous Waters in Chile; LOM Editions: Santiago, Chile, 2014. (In Spanish)

15. National Statistics Institute (INE). Preliminary Results Census of Population and Housing. Chilean Government, 2012. Available online: https://www.cooperativa.cl/noticias/site/artic/20120831/asocfile/ 20120831161553/resultados_preliminares_censo_2012.pdf (accessed on 16 August 2016).

16. National Statistics Institute (INE). Social Statistics of Indigenous People in Chile. Chilean Government, 2002. Available online: www.ine.cl/docs/default-source/FAQ/estadisticas.zip?sfvrsn=4 (accessed on 31 August 2017).

17. EducarChile. Indigenous People of Chile. 2003. Available online: http://www.educarchile.cl/ech/pro/ app / detalle?ID=185562 (accessed on 1 September 2017).

18. Sampieri, R.; Collado, C.F.; Lucio, P.B. Research Methodology; Editorial Mc Graw Hill: Mexico City, México, 2006; pp. 260-270.

19. Huerta, J. Procedure for Writing and Validating Questionnaires for Research and Evaluation Studies; University of Puerto Rico, Mayagüez Campus: Mayagüez, Puerto Rico, 2005.

20. Vicéns, J.; Medina, E. Análisis de Datos Cualitativos (Versión Electrónica). 2005. Available online: https: / / www.uam.es/personal_pdi/economicas/eva/pdf/tab_conting.pdf (accessed on 31 January 2017).

21. Buchi, H. The Economic Transformation of Chile; From Statism to Economic Freedom; Norma Editorial Group: SantaFé de Bogotá, Colombia, 1993. (In Spanish)

22. Vera, I.; Sáez, K.; Vidal, G. Performance of 14 full-scale sewage treatment plants: Comparison between four aerobic technologies regarding effluent quality, sludge production and energy consumption. Environ. Technol. 2013, 34, 2267-2275. [CrossRef] [PubMed]

23. Vera, I.; García, J.; Sáez, K.; Moragas, L.; Vidal, G. Performance evaluation of eight years' experience from constructed wetlands systems in Catalonia as alternative treatment for small communities. Ecol. Eng. 2011, 37, 364-371. [CrossRef]

24. Chamorro, S.; Hernandez, V.; Matamoros, V.; Dominguez, C.; Becerra, J.; Vidal, G.; Piña, B.; Bayona, J.M. Chemical characterization of organic microcontaminant sources and biological effects in riverine sediments impacted by urban sewage and pulp mill discharges. Chemosphere 2013, 90, 611-619. [CrossRef] [PubMed]

25. Vera, I.; Araya, F.; Andrés, E.; Sáez, K.; Vidal, G. Enhanced phosphorus removal from sewage in subsurface treatment wetland through zeolite as medium and artificial aeration. Environ. Technol. 2014, 35, 1639-1649. [CrossRef] [PubMed]

26. Yeber, M.C.; Soto, C.; Riveros, R.; Navarrete, J.; Vidal, G. Copper (II) and toxicity removal using a photocatalytic process with $\mathrm{TiO}_{2}$ as semiconductor. Chem. Eng. J. 2009, 152, 14-19. [CrossRef]

27. Dishman, C.M.; Sherrard, J.H.; Rebhun, M. Gaining public support for direct potable water reuse. J. Prof. Issues Eng. 1989, 115, 154-161. [CrossRef] 
28. Marks, J.; Cromar, N.; Fallowfield, H.; Oemcke, D. Community experience and perceptions of water reuse. Water Sci. Technol. Water Suppl. 2003, 3, 9-16.

29. Vidal, G.; Araya, F. Sewage and Its Treatment in Rural Areas: Current Situation and Challenges; Editions University of Concepcion: Concepcion, Chile, 2014; p. 118, ISBN 978-956-227-378-7.

30. Hurlimann, A.; McKay, J. Urban Australians using recycled water for domestic non-potable use-An evaluation of the attributes price, colour and odour using conjoint analysis. J. Environ. Manag. 2007, 83, 93-104. [CrossRef] [PubMed]

(C) 2018 by the authors. Licensee MDPI, Basel, Switzerland. This article is an open access article distributed under the terms and conditions of the Creative Commons Attribution (CC BY) license (http://creativecommons.org/licenses/by/4.0/). 